\title{
PLANNING IN SCIENCE
}

$I^{1}$ recent years there has keen a great deal of discussion in many countries on whether it is possible to plan science, the effect of such planning on seience and whether planning does not of necessity threaten the freedom of scientific research or limit the initiative of scientists. These issues were discussed at an international symposium sponsored by the Czecho-Slovak Union of Scientific Workers and held in Prague's Hotel International during September 19-22. Some hundred scientists were present-forty from abroad, from Great Britain, the Soviet Union, France, Brazil, India, Japan, Greece, Poland, Bulgaria, the German Democratic Republic, Rumania, Holland, Denmark, Portugal and North Korea. An observer from Unesco was also present.

The first and fundamental question raised was whether science can, by its nature, be planned at all. The participants in the symposium, without exception, agreed that planning the main tendencies of scientific research and ensuring that they are in harmony with the needs of the country and the development of science is not only possible to-day but also imperative. Naturally, the conditions for the planning of science are very different in a socialist society from those in a capitalist society. However, as pointed out by I. Malek (Czechoslovakia) : "Even though scientific development in the capitalist countries has taken its course to date without purposeful and uniform planning, the majority of scientists and public figures responsible for the development of science do not doubt the necessity of planning in some form'. P. L. Kapitza (U.S.S.R.) attributed recent spectacular Soviet scientific successes to planning: "The socialist State has great advantages in so far as the planned organization of science is concerned; this is demonstrated by the fact that it was the U.S.S.R. which had the first satellite and also was the first to reach the Moon. We do not think that the quality of our scientists is better than that of scientists of other countries. Wo are all people and we all know the same, think the same, have the same brains in our heads and our heads are of the same dimensions. But we were able to mobilize the means and the scientists and concentrate them on an important task".

The symposium then went on to discuss whether the planning of science may not become a serious obstacle barring creative research activity. Many of those present admitted that misgivings along these lines could indeed be justified in some circumstances. Care must be taken in formulating the plan, never to forget the individuals who were to carry it out. As M. M. Shemyakin (U.S.S.R.) put it : "Every bit of planning, particularly co-ordination and organization of complex research, must bear in mind the individual creative ability of the worker. Pure administration would not be in place".

Dealing with the potentialities and limitations in the planning of science it was pointed out that in scientific planning the occurrence of unexpected factors, particularly the possibility of basic discoveries in the natural sciences, must be reckoned with. As J. D. Bernal (Great Britain) pointed out: "The difficulties are very largely unforeseeable at the start and it is necessary to change course, to make use of any accidental advantage that erops up, even to abandon the whole attempt and to begin in some other direction. Even then you may not succeed in what you originally aimed at, though maybe instead you will have picked up something unforeseen and even more interesting and useful".

The problem of who should plan and guide scientific research was the subject of lively discussion during which the specific nature of planning in science, requiring special procedure and the widest participation of scientific workers, was stressed. P. L. Kapitza directed attention to the new type of scientific director needed to carry through large scientific projects. Such a director, whose role is creative rather than administrative, may be a very great man even though he himself does not work creatively in science. Interesting light on how scientific administrators are chosen in the U.S.S.R. was given by M. M. Shemyakin : "All heads of laboratories and institutes, all heads of departments at universities are elected every five years by competition in secret voting of the scientific councils. These scientific councils are set up from leading scientists of the given institute and other institutes. The directors of the Academy institutes are also elected for a period of five years from among the most important seientists, also by secret ballot of academicians and corresponding members of the Academy of Sciences of the U.S.S.R. In this way a truly democratic system of directing science is achieved and pre-conditions for control are created".

A great deal of the time of the symposium was devoted to the discussion of the difficult problem of how the results of scientific research can be appraised. It was generally agreed that the appraisal must be done by scientists and certainly not based on financial criteria. But scientists themselves are by no means able always to judge correctly whether a given line of research is likely to lead ultimately to promising results. In the final analysis, J. D. Bernal pointed out, the results of scientific research must be tested in practice. But sometimes, owing to insufficient farsighted appraisal, promising lines of research never get the possibility of practical test. This leads to a great waste of opportunity and a time-lag in putting valuable ideas into practice.

Some of the most interesting contributions to the symposium described how planning operated in practice in a number of countries. In the socialist. countries the tendency to proceed from short-term and detailed plans to long-term planning of the main trends and tasks was general. In the U.S.S.R., after a very broad discussion, thirty problems of the natural and social sciences were designated which were recognized as the most timely for the years 1959-65. The planning of science is especially thorough in Czechoslovakia, where a national plan of research including all branches of science and embracing basic and applied research right up to the production stage has been formulated by the Crechoslovak Academy of Sciences. This body is also responsible for securing the financial and material means necessary for carrying it out. Plans for scientific research in Poland. Bulgaria, the German Democratic Republic and North Korea were described. 
The only paper describing the organization of science in a Western country was given by E. H. S. Burhop (Great Britain), who pointed out that although an aggregate plan of scientific research in any sense comparable with the plans of the socialist countries does not exist in Great Britain, nevertheless, laboratories working in related fields co-ordinate their work and in the field of basic research this method of free co-operation appears to work satisfactorily. Probably applied research could benefit from more co-ordinated planning, but this met with some difficulty in a social system based on competitive private enterprise.

It would have added to the interest of the diseussion if accounts had been available of the organization of science in other Western countries. Nevertheless, the conference was of great value to participants in that it revealed both the similarities and the contrasts between the problems facing scientists in countries having different social systems.

IVAN MALEK

\section{RECENT GEOPHYSICAL WORK IN BRITAIN}

$\mathrm{A}^{\mathrm{T}}$ its meeting on January 27, the Geological Society of London held a symposium on "Geological Implications of Recent Gcophysical Work in the British Isles", under the chairmanship of the president, Dr. C. J. Stubblefield. The afternoon session, devoted to the study of igneous rock masses, was opened by Dr. M. H. P. Bott, who outlined the results of recent work on the variation of gravity over granitic intrusions ${ }^{1-3}$. Particular attention was paid to the form of the gravity profiles over two bodies with contrasting features, the Hercynian Bodmin Moor granite and the Caledonian Criffell granodiorite. In the former case a negative anomaly of about 50 milligals could only be interpreted in terms of a large density contrast (thought to be about $\left.0.16 \mathrm{gm} . / \mathrm{cm} .{ }^{3}\right)$ between granite and country rock. In contrast, a relatively small negative anomaly of some 20 milligals was recorded over the Criffell granodiorite; the gravity profile could not be straightforwardly interpreted in terms of a uniform density contrast and it was necessary to postulate a major gradational increase of density within the igneous mass towards its south-eastern margin. These conclusions, as well as the space forms deduced for the two intrusions, were not out of harmony with the results of earlier field and petrological studies. It was inferred that both intrusions extended to depths of the order of $11-12 \mathrm{~km}$., more than one third of the normal crustal thickness in continental regions.

Sir Edward Bailey questioned the assumption that there was no significant increase in the density of granites with depth, and quoted examples such as the Ben Nevis complex where the reverse had proved to be the case. Dr. A. H. Cook thought that since it was impossible to estimate densities at depth with accuracy, there was no valid evidence for denying the possibility of granite masses extending down to the Mohorovičić discontinuity. Prof. T. Murphy commented on areas of positive anomaly which flanked the gravity lows over certain Irish granites and stressed the need to consider the regional picture as a whole.

Dr. Bott also discussed the relationship which often appears to exist between the mass deficiency over a granite, calculated from the gravity anomaly, and the excess mass of the topography. This comparison led him to the suggestion that the high topography frequently associated with outcropping granites may sometimes be isostatically compensated, but within the crust rather than at its base.

Dr. D. J. Blundell described some recent investigations carried out to examine the extent to which the magnetic properties of igneous rocks might be of use in geological interpretation. He instanced his own study of the Lundy dyke swarm $^{4}$, in the course of which he was able to show that the mean direction of magnetization of the intrusions agreed with that of Tertiary lava flows. Another example cited was the work of Dr. D. Armstrong on some minor intrusives of Ayrshire ${ }^{5}$. This showed that the kylites and crinanites formed two separate suites with distinct polarization directions, the former corresponding to the known Permian direction, the lattex consistent with a Tertiary age.

Palæomagnetic work on the Newer Basic Intrusions of Aberdcenshire gave rise to some discussion. Dr. Blundell and Prof. H. H. Read ${ }^{6}$ interpreted the results as indicating that the Huntley, Insch and Belhelvio gabbros had been intruded in approximately their present attitudes and had not suffered subsequent deformation, a conclusion carrying important structural and petrogenetic implications. Prof. F. H. Stewart and Prof. R. M. Shackleton found it difficult to accept the palæomagnetic evidence as conclusive, pointing out the need for more detailed study of the geology of the Insch mass and of the effect of such features as the ore mineralogy and the thermal history on the magnotic behaviour of the rocks.

Dr. D. W. Powell quoted difference in magnetic dip between two Scottish Lower Carboniferous basalt lava sequences, both of which contained reversals, indicating polar movement during the period. He commented also on the effect of compression on rock magnetization as shown by laboratory experiments.

Mr. S. H. U. Bowie described the results of an airborne radiometric survey of Devon and Cornwall carried out for the Atomic Energy Division of the Geological Survey ${ }^{7}$. This had disclosed a relatively even level of radioactivity over the different granite masses, though individual members such as the Castle an Dinas phase of the Land's End granite, as well as kaolinized areas in general, were markedly low in activity. Acid igneous rocks gave much higher values than basic varieties and there was a general tendency for radioactivity to rise in the late differentiates of granites. On Lundy Island, however, Dr. A. T. J. Dollar had found the earlier granite to bo the most highly radioactive member of the complex.

The evening session dealt with the study of sedimentary basins and their sub-surface geology. The results of seismic work in the Carboniferous basin of the East Midlands and the Hampshire Mesozoic and Tertiary basin were outlined by Mr. R. G. W. Brunston and Mr. N. G. O'Halloran. With increasing knowledge of the general structural picture and the need for detailed exploration and study of individual structures in the course of the search for oil within 